Biological

Assessment of

Herbicide Use in

Apple Production

II. Estimated

Impacts

following Loss of
Specific
Herbicides

Jeffrey F. Derr

Additional index words. pesticide impact, tree fruit, weed control

Summary. Assessing herbicide impacts are difficult due to the indirect effects of weeds on apple (Malus domestica Borkh) growth and development. Herbicide loss will increase potential for development of herbicide-resistant weeds. A limited number of alternatives exist for herbicides currently used in apple production. Switching to certain herbicides increases potential for crop injury. Certain alternatives have higher acute toxicity or are more expensive. No alternatives exist to 2,4-D for broadleaf control in grass alleyways. Nonselective herbicides are alternatives to $2,4-\mathrm{D}$ within the row but pose a greater risk of crop injury. It is difficult to assess longterm impact of 2,4-D loss due to impact on pollination and pest management. Loss of glyphosate will result in yield losses in apple production. Most alternatives to glyphosate are less effective on perennial weed species. Paraquat, one alternative to glyphosate, poses greater hazard to the applicator due to its higher acute toxicity. Diuron is important for rotation with simazine to prevent the development of herbicide-resistance weeds. Norflurazon has an important use in recently planted orchards, where few alternatives exist for yellow nutsedge (Cyperus esculentus L.) control. Oryzalin is commonly used

$\overline{\text { Professor, Department of Plant Pathology, Physiol- }}$ ogy, and Weed Science, Virginia Tech, HRAREC, Virginia Beach, VA 23455.

The cost of publishing this paper was defrayed in part by the payment of page charges. Under postal regulations, this paper therefore must be hereby marked advertisement solely to indicate this fact. for newly planted orchards and certain alternatives can only be used on nonbearing trees. Alternatives to paraquat pose greater risk of tree injury, although there would be increased worker safety with alternative products. Glyphosate would be the predominate alternative if paraquat was no longer available. Simazine would be the predominate replacement if diuron were no longer available and diuron would be the predominant alternative if simazine was no longer registered for use. Resistance management would be negatively impacted if growers relied on simazine or diuron as their primary preemergence herbicide.

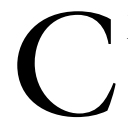
hemical control is the primary way weeds are managed in commercial apple orchards. There are concerns about loss of herbicide registrations due to reregistration and Food Quality Protection Act implementation issues. Information on the impact of loss for commonly used herbicides in apple production will be useful when assessing benefits of specific products.

A survey was sent to weed control specialists in the top 10 apple producing states (Derr, 2001). Survey respondents were asked to assess the impact of loss for the seven most frequently used herbicides in apple production. Surveys were sent to university researchers and private consultants in Washington, Oregon, California, Michigan, Ohio, New York, Pennsylvania, West Virginia, Virginia, and North Carolina.

The survey asked respondents to estimate the impact of loss of the following herbicides: 2,4-D, diuron, glyphosate, norflurazon, oryzalin, paraquat, and simazine. These seven chemicals constitute the majority of preemergence and postemergence herbicide used on apples in the United States (Derr, 2001). Respondents were asked to list the alternative chemical and nonchemical control measures that growers would use if one of these herbicides were no longer available. They were asked to estimate the percent of the apple acreage each of the alternative products would be used. The survey requested estimates on any adverse effects on crop quality, which could lead to a diversion of the crop from fresh market to juice, or on integrated pest management programs. If switching to an alternative weed control product re- sulted in reduced fruit size, for example, a proportion of the crop could be diverted to the lower-valued juice market. The survey also requested a listing of herbicides not currently registered for apple use that would improve weed management programs if they were available to growers.

A total of 15 surveys were returned out of 21 mailed to university researchers, extension personnel, and crop consultants. Surveys were returned from all states except Ohio. This report summarizes results from the returned surveys. When multiple surveys were returned from a given state, the estimated impacts were averaged. Results from the nine states were summarized into the following groups: West (Washington, Oregon, and California); Midwest (Michigan); Northeast (New York); Mid-Atlantic (Pennsylvania, West Virginia, and Virginia); and Southeast (North Carolina).

\section{Survey results}

2,4-D. Respondents estimated no yield loss if 2,4-D was no longer available (Table 1). In another survey, apple yield was expected to decrease $1.4 \%$ nationwide if 2,4 -D was no longer available (Elmore, 1996). It is difficult estimating the impact of the loss of 2,4-D on weed management in row middles due to the indirect affect on pollination and insect and disease management (Derr, 2000, 1995). Adverse effects from the loss of dandelion (Taraxacum officinale Weber in Wiggers) control in row middles may not be apparent in the first year after 2,4-D loss, but would be expected to have greater effect with time.

In the western U.S., replacement products for 2,4-D in the row would be: $58 \%$ glyphosate (with extra mowing), $15 \%$ paraquat (with extra mowing), and $27 \%$ no treatment. In the East, the replacements would be: $17 \%$ glyphosate, $10 \%$ paraquat, $3 \%$ glufosinate, $19 \%$ clopyralid, $1 \%$ sulfosate, $4 \%$ mowing, and $46 \%$ no treatment.

There currently is no replacement for 2,4-D for controlling broadleafweeds in row middles (Derr and Chandran, 2000). This is especially important for dandelion control, whose flowers compete for pollinators with fruit trees. This also impacts nematode/virus disorders that are transmitted from broadleaf weeds to apples, and insect management for weeds like buckhorn plantain (Plantago lanceolata L.). The lack of a 
replacement for 2,4-D use in the northeastern U.S. highlights this important use of 2,4-D. Since glyphosate, glufosinate, paraquat, and sulfosate are nonselective, they could not be replacements for selective broadleaf control in grass alleys. Application of glyphosate, glufosinate, paraquat, or sulfosate at rates typically used for weed control would cause severe damage to tall fescue (Festuca arundinacea Schreb.), orchardgrass (Dactylis glomerata L.), and other grasses used for ground cover in row middles. One potential chemical for broadleaf weed control in grass sod middles is clopyralid, which is currently not registered for use in apples.

Use of glyphosate poses a greater potential of tree injury, especially to nonbearing trees, than 2,4-D. Since paraquat is a contact herbicide, multiple applications would be required to provide perennial broadleaf control similar to 2,4-D. Mowing frequency would increase in several regions, leading to increased fossil fuel consumption, and potential for increased tree damage from mowing equipment and accidents injuring workers (Elmore, 1996). Certain weeds, such as field bindweed (Convolvulus arvensis L.) and dandelion would become more troublesome in orchards. Insect and disease pests would increase due to the presence of alternative weed hosts.

Diuron. Respondents estimated essentially no effect on yield or the percentage diverted to juice across the country if diuron was no longer available (Table 2). Replacement products in the West would be $65 \%$ simazine, $25 \%$ simazine plus norflurazon, 5\% norflurazon, and $5 \%$ glyphosate. In the eastern U.S., replacements would be: $57 \%$ simazine, $13 \%$ norflurazon, $14 \%$ terbacil, $9 \%$ oryzalin, $6 \%$ pendimethalin, and $1 \%$ dichlobenil. There would be increased development of triazine-resistant weeds in apple orchards since the main replacement across the country would be simazine. Build up of triazine resistant weeds would require additional postemergence sprays, and application of alternative broadleaf herbicides that are more expensive. Diuron is an inexpensive product to rotate with simazine, reducing potential for development of herbicide resistance. Besides development of herbicide-resistant weeds, weed shifts would occur if one relied primarily on one preemergence herbicide (Heeney et al., 1981).
Glyphosate. There would be an estimated 3\% yield loss in the Western U.S., with $5 \%$ of the crop diverted to juice for growers using paraquat as an alternative to glyphosate (Table 3). Most states in the eastern U.S. reported no yield loss or diversion of the crop if glyphosate use was discontinued. The Southeast, however, estimated a significant yield loss. The replacement products in the West would be: $9 \% 2,4-\mathrm{D}$, $66 \%$ paraquat, and $20 \%$ preemergence herbicides (various), with $5 \%$ no treatment. Replacement products in the East would be $19 \% 2,4-\mathrm{D}, 57 \%$ paraquat, $6 \%$ sulfosate, $16 \%$ glufosinate, and $1 \%$ sethoxydim, with $1 \%$ no treatment.

The alternative products, with the exception of sulfosate, would be less effective on perennial grasses and broadleaves. Therefore, more applications would be required of alternative products. Sulfosate would be an acceptable alternative to glyphosate but currently this product is only registered for use on nonbearing apples. Also, due to the very close chemical structure of glyphosate and sulfosate, it is likely that loss in registration for one of these chemicals would also result in loss of the other one.

Table 1. Alternatives that apple growers would utilize and the resulting impacts if 2,4-D use was discontinued.

\begin{tabular}{|c|c|c|c|c|c|}
\hline $\begin{array}{l}\text { U.S. } \\
\text { region }^{z}\end{array}$ & Alternative ${ }^{y}$ & $\begin{array}{c}\text { Rate } \\
\text { (a.i.) } \\
\text { (lb/acre) }^{x}\end{array}$ & $\begin{array}{c}\text { Applications } \\
\text { (no.) }\end{array}$ & $\begin{array}{c}\text { Proportion } \\
\text { of } 2,4-D \\
\text { use replaced } \\
(\%)\end{array}$ & $\begin{array}{c}\text { Change in } \\
\text { crop yield } \\
(\%)\end{array}$ \\
\hline \multirow[t]{5}{*}{ West } & Glyphosate & 1.0 & 1.5 & 53 & 0 \\
\hline & + mowing & & 1.5 & & \\
\hline & Glyphosate & 1.0 & 2.0 & 5 & 0 \\
\hline & Paraquat & 0.75 & 2.0 & 2 & 0 \\
\hline & No treatment & & & 27 & 0 \\
\hline \multirow[t]{3}{*}{ Midwest } & Glyphosate & 1.0 & 1.5 & 40 & 0 \\
\hline & Paraquat & 1.0 & 2.0 & 20 & 0 \\
\hline & Glufosinate & 1.0 & 1.0 & 3 & 0 \\
\hline & Paraquat & 0.8 & 2.3 & 16 & 0 \\
\hline & Glufosinate & 0.75 & 1.8 & 9 & 0 \\
\hline & Mowing & 1.0 & 16 & 0 & \\
\hline & No treatment & & & 42 & 0 \\
\hline \multirow[t]{4}{*}{ Southeast } & Glyphosate & 1.5 & 1.0 & 10 & 0 \\
\hline & Paraquat & 0.9 & 1.0 & 5 & 0 \\
\hline & Clopyralid & 0.25 & 1.0 & 75 & 0 \\
\hline & No treatment & & & 10 & 0 \\
\hline
\end{tabular}

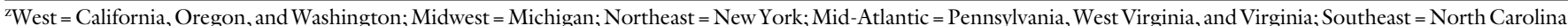
yCertain respondents estimated that herbicide application combined with additional mowing would be the alternative growers would use if 2,4 - $\mathrm{D}$ was not available.

${ }^{\mathrm{x}} 1.0 \mathrm{lb} / \mathrm{acre}=1.12 \mathrm{~kg} \cdot \mathrm{ha}^{-1}$. 
Table 2. Alternatives that apple growers would use and the resulting impacts if diuron use was discontinued.

\begin{tabular}{|c|c|c|c|c|c|}
\hline $\begin{array}{l}\text { U.S. } \\
\text { region }^{z}\end{array}$ & Alternative $^{\mathrm{y}}$ & $\begin{array}{c}\begin{array}{c}\text { Rate } \\
\text { (a.i.) }\end{array} \\
\text { (lb/acre) }^{x} \\
\end{array}$ & $\begin{array}{c}\text { Applications } \\
\text { (no.) }\end{array}$ & $\begin{array}{c}\text { Proportion } \\
\text { of diuron } \\
\text { use replaced } \\
(\%)\end{array}$ & $\begin{array}{c}\text { Change in } \\
\text { crop yield } \\
(\%)\end{array}$ \\
\hline \multirow[t]{3}{*}{ West } & Simazine & 1.5 & 1.3 & 65 & 0 \\
\hline & Norflurazon & 1.5 & 1.0 & 5 & 0 \\
\hline & Glyphosate & 1.0 & 2.0 & 5 & 0 \\
\hline \multirow[t]{4}{*}{ Midwest } & Simazine & 2.0 & 1.0 & 60 & 0 \\
\hline & Norflurazon & 2.0 & 1.0 & 20 & 0 \\
\hline & Terbacil & 0.75 & 1.0 & 10 & 0 \\
\hline & Oryzalin & 2.0 & 1.0 & 10 & 0 \\
\hline Northeast & Norflurazon & 2.4 & 1.0 & 25 & 0 \\
\hline \multirow{4}{*}{ Mid-Atlantic } & Norflurazon & 2.5 & 1.0 & 6 & 0 \\
\hline & Oryzalin & 3.0 & 1.0 & 1 & 0 \\
\hline & Oxyfluorfen & 1.8 & 1.0 & 2 & 0 \\
\hline & Terbacil & 1.5 & 1.0 & 10 & 0 \\
\hline \multirow[t]{3}{*}{ Southeast } & Simazine & 2.0 & 1.0 & 85 & -10 \\
\hline & Terbacil & 2.0 & 1.0 & 10 & 0 \\
\hline & Dichlobenil & 6.0 & 1.0 & 5 & 0 \\
\hline
\end{tabular}

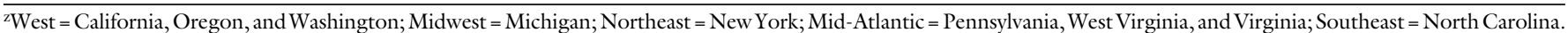
yCertain respondents indicated that a combination of two herbicides would be needed if diuron was not available.

${ }^{\mathrm{x}} 1.0 \mathrm{lb} / \mathrm{acre}=1.12 \mathrm{~kg} \cdot \mathrm{ha}^{-1}$.

Table 3. Alternatives that apple growers would use and the resulting impacts if glyphosate use was discontinued.

\begin{tabular}{|c|c|c|c|c|c|c|}
\hline $\begin{array}{l}\text { U.S. } \\
\text { region }^{z}\end{array}$ & Alternative $^{\mathrm{y}}$ & $\begin{array}{c}\text { Rate } \\
\text { (a.i.) } \\
\text { (lb/acre) }^{\text {w }}\end{array}$ & $\begin{array}{c}\text { No. of } \\
\text { applications } \\
\text { (no.) }\end{array}$ & $\begin{array}{c}\text { Proportion } \\
\text { of glyphosate } \\
\text { use replaced } \\
(\%) \\
\end{array}$ & $\begin{array}{c}\text { Change } \\
\text { crop yield } \\
(\%)\end{array}$ & $\begin{array}{l}\text { Proportion } \\
\text { of the crop } \\
\text { diverted } \\
\text { to juice } \\
(\%)\end{array}$ \\
\hline \multirow[t]{6}{*}{ West } & 2,4-D & 1.4 & 1.3 & 9 & -10 & 0 \\
\hline & Simazine & 2.0 & 1.0 & 5 & 0 & 0 \\
\hline & Oryzalin + & 2.0 & 1.0 & 5 & -5 & 0 \\
\hline & oxyfluorfen & 1.0 & & & & \\
\hline & Paraquat & 0.8 & 1.9 & 66 & -3 & 5 \\
\hline & No treatment & & & 5 & -20 & 0 \\
\hline Midwest & $2,4-\mathrm{D}$ & 1.0 & 1.5 & 40 & 0 & 0 \\
\hline \multirow[t]{6}{*}{ Mid-Atlantic } & Glufosinate & 0.85 & 1.5 & 27 & 0 & 0 \\
\hline & 2,4-D & 1.5 & 1.5 & 31 & -1 & 0 \\
\hline & Paraquat & 0.7 & 2.1 & 28 & 0 & 0 \\
\hline & Sulfosate & 3.0 & 1.0 & 8 & 0 & 0 \\
\hline & Terbacil & 1.6 & 2.0 & 1 & 0 & 0 \\
\hline & No treatment & & & 5 & 0 & 0 \\
\hline \multirow[t]{4}{*}{ Southeast } & Paraquat & 0.9 & 2.0 & 60 & -35 & 0 \\
\hline & Glufosinate & 1.0 & 2.0 & 30 & -30 & 0 \\
\hline & 2,4-D & 1.0 & 1.2 & 5 & 0 & 0 \\
\hline & Sethoxydim & 0.28 & 1.0 & 5 & 0 & 0 \\
\hline
\end{tabular}

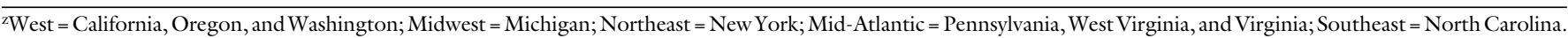
${ }^{y}$ Certain respondents ndicated that a combination of two herbicides would be needed if glyphosate was not available.

${ }^{\mathrm{x}} \mathrm{A}$ reduction in fruit quality could lead to the crop being diverted from the fresh market to the lower-valued juice market.

w $1.0 \mathrm{lb} / \mathrm{acre}=1.12 \mathrm{~kg} \cdot \mathrm{ha}^{-1}$. 
Table 4. Alternatives that apple growers would utilize and the resulting impacts if norflurazon use was discontinued.

\begin{tabular}{|c|c|c|c|c|c|}
\hline $\begin{array}{l}\text { U.S. } \\
\text { region }^{\mathrm{z}}\end{array}$ & Alternative $^{y}$ & $\begin{array}{c}\begin{array}{c}\text { Rate } \\
(\text { a.i. }) \\
\text { (lb/acre) }^{x}\end{array} \\
\end{array}$ & $\begin{array}{c}\text { Applications } \\
\text { (no.) }\end{array}$ & $\begin{array}{c}\text { Proportion } \\
\text { of norflurazon } \\
\text { use replaced } \\
(\%)\end{array}$ & $\begin{array}{c}\text { Change in } \\
\text { crop yield } \\
(\%)\end{array}$ \\
\hline \multirow[t]{8}{*}{ West } & Simazine & 1.5 & 1.3 & 40 & 0 \\
\hline & Diuron & 1.5 & 1.3 & 17 & 0 \\
\hline & Oryzalin + & 1.5 & 1.0 & 10 & 0 \\
\hline & oxyfluorfen & 1.0 & & & \\
\hline & Simazine + & 3.0 & 1.0 & 17 & 0 \\
\hline & oryzalin & 3.0 & 1.0 & & \\
\hline & Isoxaben & 1.0 & 1.0 & 13 & 0 \\
\hline & No treatment & & & 3 & \\
\hline \multirow[t]{4}{*}{ Midwest } & Simazine & 2.0 & 1.0 & 75 & 0 \\
\hline & Diuron & 2.0 & 1.0 & 5 & 0 \\
\hline & Terbacil & 0.75 & 1.0 & 5 & 0 \\
\hline & Oryzalin & 2.0 & 1.0 & 15 & 0 \\
\hline \multirow[t]{2}{*}{ Northeast } & Paraquat & 0.5 & 2.0 & 50 & 0 \\
\hline & Glyphosate & 1.5 & 2.0 & 50 & 0 \\
\hline \multirow[t]{7}{*}{ Mid-Atlantic } & Simazine & 2.8 & 1.3 & 19 & 0 \\
\hline & Diuron & 3.3 & 1.5 & 16 & 0 \\
\hline & Glyphosate & 1.8 & 2.0 & 1 & 0 \\
\hline & Glufosinate & 0.75 & 2.0 & 1 & 0 \\
\hline & Gryzalin & 2.0 & 1.0 & 52 & 0 \\
\hline & Napropamide & 4.0 & 1.0 & 8 & 0 \\
\hline & Terbacil & 0.8 & 1.0 & 3 & 0 \\
\hline \multirow[t]{2}{*}{ Southeast } & Oryzalin & 2.0 & 1.0 & 90 & 0 \\
\hline & Pendimethalin & 3.0 & 1.0 & 10 & 0 \\
\hline
\end{tabular}

${ }^{\mathrm{z}}$ West $=$ California, Oregon, and Washington Midwest $=$ Michigan; Northeast = New York; Mid-Atlantic = Pennsylvania, West Virginia, and Virginia $;$ Southeast = North Carolina. yCertain respondents ndicated that a combination of two herbicides would be needed if norflurazon was not available.

${ }^{\mathrm{x}} 1.0 \mathrm{lb} / \mathrm{acre}=1.12 \mathrm{~kg} \cdot \mathrm{ha}^{-1}$

Table 5. Alternatives that apple growers would utilize and the resulting impacts if oryzalin use was discontinued.

\begin{tabular}{|c|c|c|c|c|c|}
\hline $\begin{array}{l}\text { U.S. } \\
\text { region }^{z}\end{array}$ & Alternative ${ }^{y}$ & $\begin{array}{c}\text { Rate } \\
\text { (a.i.) } \\
\text { (lb/acre) }^{\mathbf{w}} \\
\end{array}$ & $\begin{array}{c}\text { No. of } \\
\text { applications } \\
\text { (no.) }\end{array}$ & $\begin{array}{c}\text { Proportion } \\
\text { of oryzalin } \\
\text { use replaced } \\
(\%) \\
\end{array}$ & $\begin{array}{c}\text { Proportion } \\
\text { of the crop } \\
\text { diverted } \\
\text { to juice } \\
(\%)\end{array}$ \\
\hline \multirow[t]{7}{*}{ West } & Pendimethalin & 2.0 & 1.3 & 42 & 0 \\
\hline & Norflurazon & 1.5 & 1.0 & 5 & 0 \\
\hline & Glyphosate & 1.0 & 1.0 & 5 & 0 \\
\hline & Isoxaben & 0.5 & 1.0 & 13 & 10 \\
\hline & Oxyfluorfen + & 1.0 & 1.0 & 13 & 0 \\
\hline & pronamide & 2.0 & & & \\
\hline & Paraquat & 0.6 & 2.5 & 22 & 0 \\
\hline \multirow[t]{4}{*}{ Midwest } & Napropamide & 4.0 & 1.0 & 30 & 0 \\
\hline & Norflurazon & 2.0 & 1.0 & 40 & 0 \\
\hline & Simazine & 2.0 & 1.0 & 20 & 0 \\
\hline & Terbacil & 0.75 & 1.0 & 10 & 0 \\
\hline Northeast & Pendimethalin & 4.0 & 1.0 & 100 & 0 \\
\hline \multirow[t]{7}{*}{ Mid-Atlantic } & Norflurazon & 2.0 & 1.2 & 72 & 0 \\
\hline & Diuron & 2.4 & 2.0 & 7 & 0 \\
\hline & Simazine & 3.5 & 2.0 & 7 & 0 \\
\hline & Paraquat & 1.25 & 2.0 & 2 & 0 \\
\hline & Napropamide & 4.0 & 1.0 & 8 & 0 \\
\hline & Pendimethalin & 3.0 & 1.0 & 3 & 0 \\
\hline & No treatment & & & 1 & 0 \\
\hline \multirow[t]{3}{*}{ Southeast } & Norflurazon & 2.0 & 1.0 & 90 & 0 \\
\hline & Pendimethalin & 3.0 & 1.0 & 8 & 0 \\
\hline & Napropamide & 4.0 & 1.0 & 2 & 0 \\
\hline
\end{tabular}

${ }^{\mathrm{z}}$ West $=$ California, Oregon, and Washington; Midwest = Michigan; Northeast = New York; Mid-Atlantic = Pennsylvania, West Virginia, and Virginia $;$ Southeast = North Carolina. ${ }^{y}$ Certain respondents indicated that a combination of two herbicides would be needed if oryzalin was not available.

${ }^{\mathrm{x}} \mathrm{A}$ reduction in fruit quality could lead to the crop being diverted from the fresh market to the lower-valued juice market

${ }^{\mathrm{w}} 1.0 \mathrm{lb} / \mathrm{acre}=1.12 \mathrm{~kg} \cdot \mathrm{ha}^{-1}$. 
The increased use of paraquat poses an additional hazard to the applicator due to the higher acute toxicity of this herbicide (Ahrens, 1994). There would be an increase in perennial grasses and broadleaves since most of the alternatives are less effective on these weeds. Preemergence herbicide use would increase. Increased cultivation would increase soil erosion and fossil fuel consumption. Rodent control would de- crease due to lower overall weed control. There would, however, be less herbicide injury to fruit trees by switching to the alternatives since glyphosate has greater systemic activity than most alternatives.

Norfurazon. There would be no impact on crop yield or the percentage diverted to juice if norflurazon was no longer available (Table 4). Replacement products in the west would be $40 \%$ simazine, $17 \%$ diuron, $10 \%$ oryzalin plus oxyfluorfen, $17 \%$ simazine plus oryzalin, and $13 \%$ isoxaben, with $3 \%$ no treatment. Replacement products in the east would be: $23 \%$ simazine, $5 \%$ diuron, $2 \%$ terbacil, 39\% oryzalin, 13\% paraquat, $13 \%$ glyphosate, $2 \%$ napropamide, and $3 \%$ pendimethalin. Yellow nutsedge and annual grass control would decrease with some of the alternative products. An effective herbicide for newly planted

Table 6. Alternatives that apple growers would utilize and the resulting impacts if paraquat use was discontinued.

\begin{tabular}{|c|c|c|c|c|c|}
\hline $\begin{array}{l}\text { U.S. } \\
\text { region }^{z}\end{array}$ & Alternative $^{\mathrm{y}}$ & $\begin{array}{c}\begin{array}{c}\text { Rate } \\
(\text { a.i. }) \\
\text { (lb/acre) }^{x}\end{array} \\
\end{array}$ & $\begin{array}{c}\text { Applications } \\
\text { (no.) }\end{array}$ & $\begin{array}{c}\text { Proportion } \\
\text { of paraquat } \\
\text { use replaced } \\
(\%) \\
\end{array}$ & $\begin{array}{c}\text { Change in } \\
\text { crop yield } \\
(\%)\end{array}$ \\
\hline \multirow[t]{2}{*}{ West } & Glyphosate & 0.8 & 1.5 & 83 & 0 \\
\hline & Glufosinate & 0.75 & 3.0 & 17 & 0 \\
\hline \multirow[t]{2}{*}{ Midwest } & Glyphosate & 1.0 & 1.2 & 75 & 0 \\
\hline & Terbacil & 0.75 & 1.0 & 3 & 0 \\
\hline Northeast & Glyphosate & 1.5 & 1.1 & 100 & 0 \\
\hline \multirow[t]{3}{*}{ Mid-Atlantic } & Glyphosate & 1.6 & 1.6 & 61 & 0 \\
\hline & Sulfosate & 1.0 & 1.0 & 8 & 0 \\
\hline & Glufosinate & 0.76 & 2.0 & 24 & 0 \\
\hline
\end{tabular}

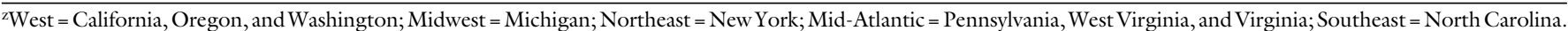
y $1.0 \mathrm{lb} /$ acre $=1.12 \mathrm{~kg} \cdot \mathrm{ha}^{-1}$.

Table 7. Alternatives that apple growers would utilize and the resulting impacts if simazine use was discontinued.

\begin{tabular}{|c|c|c|c|c|c|}
\hline $\begin{array}{l}\text { U.S. } \\
\text { regionz }^{\mathrm{z}}\end{array}$ & Alternative & $\begin{array}{c}\text { Rate } \\
\text { (a.i.) } \\
\text { (lb/acre) }^{x} \\
\end{array}$ & $\begin{array}{c}\text { Applications } \\
\text { (no.) }\end{array}$ & $\begin{array}{c}\text { Proportion } \\
\text { of simazine } \\
\text { use replaced } \\
(\%)\end{array}$ & $\begin{array}{c}\text { Proportion } \\
\text { of the crop } \\
\text { diverted } \\
\text { to juice } \\
(\%)\end{array}$ \\
\hline \multirow[t]{2}{*}{ West } & Diuron & 1.4 & 1.2 & 63 & 5 \\
\hline & Norflurazon & 1.7 & 1.0 & 30 & 5 \\
\hline \multirow[t]{4}{*}{ Midwest } & Diuron & 2.0 & 1.3 & 30 & 0 \\
\hline & Terbacil & 0.75 & 1.0 & 30 & 0 \\
\hline & Oryzalin & 2.0 & 1.0 & 20 & 0 \\
\hline & Norflurazon & 2.0 & 1.0 & 20 & 0 \\
\hline Northeast & Diuron & 2.2 & 1.5 & 87 & 0 \\
\hline \multirow{3}{*}{ Mid-Atlantic } & Norflurazon & 2.0 & 1.5 & 7 & 0 \\
\hline & Oxyfluorfen & 1.0 & 1.0 & 2 & 0 \\
\hline & Oryzalin & 1.9 & 1.0 & 6 & 0 \\
\hline \multirow[t]{2}{*}{ Southeast } & Diuron & 2.0 & 1.0 & 90 & 0 \\
\hline & Terbacil & 2.0 & 1.0 & 10 & 0 \\
\hline
\end{tabular}

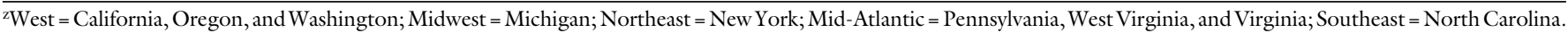
yA reduction in fruit quality could lead to the crop being diverted from the fresh market to the lower-valued juice market.

${ }^{\mathrm{x}} 1.0 \mathrm{lb} /$ acre $=1.12 \mathrm{~kg} \cdot \mathrm{ha}^{-1}$. 
apple trees would be lost. Most of the replacement products can only be used in established trees. Isoxaben and pendimethalin are only labeled for use in nonbearing apples, limiting their potential as replacements. Increased use of simazine would be expected to cause further development of resistant weeds.

Oryzalin. There would be essentially no effect on crop yield if oryzalin was no longer available due to the availability of alternatives (Table 5). Replacement products in the West would be: $42 \%$ pendimethalin, $5 \%$ norflurazon, $5 \%$ glyphosate, $13 \%$ isoxaben, $13 \%$ oxyfluorfen plus pronamide, and 22\% paraquat. Replacement products in the East would be: $10 \%$ napropamide, $28 \%$ pendimethalin, 51\% norflurazon, 7\% simazine, $2 \%$ terbacil, and $2 \%$ diuron. There would be loss of an important herbicide for newly planted trees. Annual grass control, including goosegrass [Elesuine indica (L.) Gaertn.], would decline with some of the alternatives. Two of the alternative products, pendimethalin and isoxaben, are only available for use on nonbearing apples.

Paraquat. There would be essentially no effect on crop yield if paraquat was no longer available due to the availability of alternatives (Table 6). Replacement products in the west would be $83 \%$ glyphosate, and $17 \%$ glufosinate. Replacement products in the east would be $77 \%$ glyphosate, $6 \% 2,4-\mathrm{D}, 3 \%$ si- $^{-}$ mazine, $2 \%$ sulfosate, and $12 \%$ glufosinate. Alternative products are more expensive, and there would be increased potential for tree damage with use of the alternative products. However, there would be greater worker safety by switching to these alternatives due to their lower acute toxicity. Weeds would be harder to control in young and dwarf plantings, due to the increased injury potential from alternative herbicides. Potential for development of glyphosate resistance would increase since this would be the primary alternative.

Simazine. There would be a small diversion of the crop to juice in the West if simazine was no longer available, with no effect on crop yield in the East (Table 7). Diuron is a suitable alternative to simazine use. Herbicide resistance would be a concern if growers primarily used diuron for annual broadleaf weed control.

Replacement products in the West would be $63 \%$ diuron, $30 \%$ norflurazon, $5 \%$ oxyfluorfen, and $2 \%$ oryzalin. Re- placement products in the East would be $71 \%$ diuron, $15 \%$ terbacil, $7 \%$ oryzalin, and $7 \%$ norflurazon. Cost of weed control would increase. There would be a decrease in control of certain broadleaves, such as horseweed [ Conyza canadensis (L.) Cronq.] and fleabane (Erigeron L.).

Diuron would not be an effective alternative to simazine in the west since horseweed and fleabane are two very important weeds infesting orchards. These weeds are difficult to control postemergence when they are 4 inches $(10.2 \mathrm{~cm})$ tall. An inexpensive product for rotation with diuron would be lost. In the West, herbicide-resistant weeds have not been a problem due to herbicide rotation. Simazine is therefore a needed component of a resistance management program. Triazine-resistant weeds have been identified in European orchards and in corn production in North America and Europe (Bulcke et al., 1998; Heap, 1997).

Herbicides not currently regisTERED BUT NEeDED. Respondents listed several herbicides not currently registered for use on apples that would improve weed management programs. The chemicals listed were azafenidin, clopyralid, thiazopyr, and triclopyr. Development of labels for bearing trees for products such as pendimethalin and sulfosate that are currently only labeled for nonbearing apples was also mentioned by the respondents.

\section{Summary and conclusions}

Alternatives are available for most products used for weed control in orchards. One important exception would be selective broadleaf weed control in row middles if 2,4-D were lost since no alternative exists. Some alternatives are not registered for use on bearing crops so labeling of alternatives would need to be expanded to minimize impacts. Estimates of alternative products used if a herbicide was discontinued were similar among the major apple producing states.

Development of herbicide resistance would be an important concern with loss of a given herbicide. Due to the limited number of alternative products available to fruit growers, producers would be expected to switch predominately to one alternative. Losing the ability to rotate herbicides with different modes of action would result in the buildup of resistant weeds.

It is very difficult estimating the impact of herbicide use on fruit produc- tion. This is due to the indirect effect of weeds on apples through competition for nutrients, water, and pollination, allelopathy, and harboring of insect, disease and rodent pests. Research data comparing crop yield and quality for alternative products is generally lacking.

The primary impacts of loss for a specific herbicide would be on weed species shifts, costs of alternatives, safety of alternatives to workers, potential for tree injury with alternatives, and increases in insect and disease pests. Certain alternatives, such as glyphosate, pose the risk of greater crop injury. Crop yields could be affected if growers were forced to switch to such alternatives. Impact of increasing pest populations or increased herbicide damage to trees is difficult to estimate. Loss of glyphosate would result in reduced crop yield in certain sections of the country. For other herbicides, cancellation would not be expected to adversely affect apple yield or quality, especially in the short term. Adverse effects on crop yield in the long term could be greater than the estimates provided in this report if switching to alternative products leads to increased pest populations, herbicide injury, or herbicide resistance. Registration of new herbicides for apple use would be beneficial since growers currently rely on a relatively few number of herbicides.

\section{Literature cited}

Ahrens, W.H. (ed.). 1994. Herbicide handbook, Weed Sci. Soc. Amer., Lawrence, Kan.

Bulcke, R., D. Callens, and J. Maillet. 1998. Herbicide resistance in weeds-What to learn from forty years of long-term herbicide experiments in apple and pear orchards? Proc. 6th Symp. Mediterraneen EWRS p. 173-180.

Derr, J.F and R.S. Chandran. 2000. Chemical control of weeds, p. 92-106. In: 2000 Spray bulletin for commercial tree fruit growers. Va. Coop. Ext. Publ. 456-419.

Derr, J.F. 2001. Biological assessment of herbicide use in apple production. I. Background and current use estimates. HortTechnology 11(1):11-19.

Derr, J.F. 1995. Weeds, p. 147-155. in Mid-Atlantic orchard monitoring guide. Publ. NRAES-75 N.E. Reg. Agr. Eng. Serv. Coop. Ext., Ithaca, N.Y.

Elmore, C.L. 1996. Use of 2,4-D in orchards, vineyards, and soft fruit in the United States, p. 148-164. In: Biologic and economic assessment of benefits from use of phenoxy herbicides in the United States. USDA/ NAPIAP Rpt. 1-PA-96.

Heap, I.M. 1997. The occurrence of herbicide-resis tant weeds worldwide. Pesticide Sci. 51:235-243.

Heeney, H.B., V. Warren, and S.U. Khan. 1981 Effects of a rotation of simazine, terbacil, and dichlobenil in a mature apple orchard. Can. J. Plant Sci. 61:407411 . 